\title{
Student Pavilion UNIMAS for Platinum Green Building Index
}

\author{
A.Baharun, S.H. Ibrahim, R. Affandi, and P.G. Goh
}

\begin{abstract}
Green Building Index is a rating tool to evaluate a building on its sustainability. Student Pavilion in UNIMAS is a green building to cater with the GBI rating. In this study, it looks into the current facility that the building has according to six(6) criteria: energy efficiency, indoor environmental quality, sustainable site planning and management, material and resources, water efficiency, and innovation. Each criterion is evaluated accordingly to its tasks. The building of Student Pavilion has an Overall Thermal Transfer Value of 34.08 which is less than 50 as required by GBI rating guidelines. The facility is greatly relying on natural day light, when the illuminance in the room is less than 300 lux, artificial light is switched on, to fill the insufficient illuminance. There is electrical sub-metering for each tenant to monitor and diagnose the usage of electric. Solar panel at Student Pavilion can annually provide $5537.4 \mathrm{kWhr} / \mathrm{year}$ but it is insufficient to support the total electric usage of the building. Besides that, the thermal comfort of Student Pavilion is within the range of thermal comfort except for the food court area as the building is designed and built to allow for maximum wind flow and air exchange so that it would not rely on air-conditioning system. The building materials and transportation to the site is also considered in GBI. Furthermore, the water demand and rainwater harvesting at Student Pavilion is determined and it was found that the current supply of rainwater harvesting is not enough to cater with the demand of the occupants, hence larger volume of rainwater harvesting storage should be provided. The current green facility of Student Pavilionshould be improved in order to achieve Platinum in GBI.
\end{abstract}

Keywords: Green Building Index; Energy Efficiency; Renewable Energy.

\section{INTRODUCTION}

$\mathrm{G}$ LOBAL warming is a major concern all over the world. It brings negative impacts to the environment to both living and non-living thing. This phenomenon happens due to the cumulative effect of hundreds of environmental factors. One of the greatest contributors to global warming is the building industry. According to the World Green Building Council, worldwide buildings account for 33 percent of carbon dioxide emissions, 30-40 percent of the world's energy consumption and 40-50 percent of raw materials used [1]. So, in the concern of environment, different organizations from all over the world have set up their own codes and rating systems to evaluate a building towards green. These are some examples of green building rating tools: BREEAM (United Kingdom), CASBEE (Japan), LEED (United States) and Green Star (Singapore). In Malaysia, Green Building Index is set up as a rating tool for green building. Green Building Index (GBI) is developed in 2009 by PertubuhanArkitek Malaysia (PAM) and the Association of Consulting Engineers Malaysia (ACEM).

Malaysian Government's way forward is towards green technology which act as a catalyst for economic growth along the low-carbon trajectory in Malaysia. Therefore UNIMAS decided to participate in green campus constituent and constructed a green building in the campus namely Student Pavilion. In order to achieve the Platinum standard in Malaysia's Green Building Index, Student Pavilion need to at least obtain 86 points and above in GBI rating. The points are given according to six categories and each category consists of several tasks, each task consists of points. The six categories are Energy Efficiency (EE), Indoor Environmental Quality (EQ), Sustainable Site Planning \& Management (SM), Material \& Resources (MR), Water Efficiency (WE) and Innovation (IN). The existence of this tool is intended to promote sustainability in the built environment and raise awareness among developers, architects, engineers, planners, designers, contractors and the public on environmental issues.

Student Pavilion UNIMAS was proposed to gain the Platinum Rating of GBI. The building for students activities is evaluated by the energy and water usage, comfort along with the construction materials for the building itself.

\section{ENERGY EFFICIENCY}

According to KementerianTenaga, TeknologiHijaudan Air Malaysia (KeTTHA), energy efficiency is defined as the efficient use of energy in a manner that utilizes less energy for producing the same output [2]. In Malaysia, energy efficiency had been highlighted in 9th Malaysia Plan which indicates that the building should be designed to optimize energy usage [4]. In Malaysia, the highest portion of energy consumption by a building is air-conditioning system (64\%), followed by general equipment (24\%), then lighting (12\%) [5] and [6]. An energy efficiency building consists of some basic elements such as a

A.Baharun,Associate Professor, Department of Civil Engineering, Faculty of Engineering, Kota Samarahan, Sarawak,

Malaysia(,bazhaili@feng.unimas.my)

S.H Ibrahim,Senior Lecturer, Department of Civil Engineering, Faculty of Engineering, Kota Samarahan, Sarawak, Malaysia, ,

R. Affandi,Lecturer,Department of Civil Engineering, Faculty of Engineering, Kota Samarahan, Sarawak, Malaysia

P.G. Goh,Undergraduate student,Department of Civil Engineering, Faculty of Engineering, Kota Samarahan, Sarawak, Malaysia, 


\section{UNIMAS e-Journal of Civil Engineering: Volume 5, Issue 1}

well-constructed and tightly sealed thermal envelope; controlled ventilation; properly sized; high efficiency heating and cooling systems; and energy-efficient doors, windows, and appliances. By having energy-efficiency building envelope, it is proved that the building will significantly affect the energy usage. Energy efficiency is easy to incorporate in the initial construction of a building, but it is expensive to retrofit. The overall thermal transfer value (OTTV) concept was initially introduced in the ASHRAE Standard 90A-1980 [7]. The OTTV method is used as a measurement of the energy consumption for building envelope design in commercial building and hotels [8]. For Malaysia, OTTV is calculated for the residential building envelope designs [9]. It is the design parameter that indicates the solar thermal load transmitted through the building envelope excluding roof [10]. According to KeTTHA, renewable energy is defined as any form of primary energy from recurring and non-depleting resources, such as agricultural produce, hydro-power, wind, solar etc. [2]. Malaysia is currently dependent on the usage of oil, natural gas and coal as a source to generate energy although Malaysia has exploited on renewable energy such as hydro power, solar power and biomass. However, this non-renewable energy is diminishing. According to the estimation of International Energy Agency, at year 2030, global energy consumption will be increased by $53 \%$ with $73 \%$ of the growth in demand coming from developing countries [11]. Since Malaysia economy is rapidly growing therefore overall energy demand is expected to increase at an average rate of $6 \%$ per annum [12]. Since the demand is increasing every year, the non-renewable energy such as natural gas, oil and coal is decreasing and one day these resources will be finished. So, it is important to reduce the dependent on non-renewable energy but renewable energy sources such as solar, wind and biomass.

\section{INDOOR AIR QUALITY}

Wesolowski[13] define indoor air quality as 'the totality of attributes of indoor air that affect a person's health and wellbeing'. Indoor air quality is the quality of air in a particular building. Poor indoor air quality leads to some common sickness like sick building syndrome [13]. Malaysia is a hot and humid tropical country. It lies between $1^{\circ}$ to $7^{\circ} \mathrm{N}$ and $100^{\circ}$ to $120^{\circ} \mathrm{E}$ with an annually mean temperature of between $26^{\circ} \mathrm{Cand} 28^{\circ} \mathrm{C}$. Besides that, Malaysia has high-daytime temperatures of 29 $34^{\circ} \mathrm{C}$ and relative humidity of $70-90 \%$ throughout the year. Air-conditioning system is a demand by the society as the society has becoming more affluent. Due to this kind of trend, in recent years, Malaysia's energy consumption has increased; in 2002 the energy consumption was $2.8 \mathrm{MWh}$ per capita. Studies have been conducted in the area of thermal comfort to find means to provide comfortable indoor environments to reduce energy consumption and costs [14].

\section{WATER EFFICIENCY}

Water efficiency is defined as the accomplishment of a function, task, process, or result with the minimal amount of water feasible; an indicator of the relationship between the amounts of water used or delivered [15]. Water efficiency means using improved technologies and practices that deliver equal or better service with less water. For example, the use of low-flow faucet aerators can be more powerful than no aerators for washing hands. Water conservation has been associated with curtailment of water use and doing "less" with less water typically during a water shortage, such as a drought; for example, minimizing lawn watering and automobile washing in order to conserve water. Water conservation also includes day-to-day "demand management" to better manage how and when water is used, so it is common to hear the words "water conservation" used synonymously with "water efficiency" [16].

\section{METHODOLOGY}

The objectives of this study were achieved by using four (4) methods. The four methods carried out were through literature review, measuring data, interview with construction parties and site visit. Through the literature review, information about the topic of the study and up-to-date issues had been studied. Secondly, the data of the ambient temperature, illuminance, water and energy usage measurements were collected for analysis. The temperature were collected hourly using thermocouple type $\mathrm{K}$ attached to a data logger, while the luminance level were measured using a lux-meter and energy usage were monitored using a watt meter. Thirdly, by reviewing the blueprints and conducting interview with construction and management parties who are involved directly and indirectly in the construction of the Student Pavilion to obtain more information on construction materials of the building. Finally, a site visit to Student Pavilion to observe the environment and site planning and suitability before the building start to operate.

\section{RESULTS AND DISCUSSION}

\section{A. Overall Thermal Transfer Value (OTTV)}

The OTTV for Student Pavilion is 34, which is less than 50 as one of the requirement by GBI for the certification guideline. OTTV is a measure of average rate of heat transfer from external environment into a building via the building envelope. Less OTTV meaning that the heat gained by the building is less and it reduces the cooling load of the air-conditioning system thus reducing the carbon dioxide [17]. 


\section{B. Renewable Energy}

Student Pavilion is equipped with renewable energy device that is derived from Building Integrated Photovoltaic (BIPV). There is a photovoltaic (PV) at the roof top of multi-purpose hall. The photovoltaic system is grid connected to SESCO and produces non-polluting electricity for electricity grid. The total capacity of the BIPV installed is $5.20 \mathrm{kWp}$. It is estimated to achieve about $5 \%$ of the energy needs of the building. Table 1 shows the details of solar energy yield by BIPV. The RE generated will help in reducing the net Building Energy Index to achieve some requirement by GBI calculation.

Table 1: Solar energy yield by BIPV

\begin{tabular}{|l|c|}
\hline Total installed BIPV & $5.20 \mathrm{kWp}$ \\
\hline Estimated annual energy yield & $1064.88 \mathrm{kWh} / \mathrm{kW} / \mathrm{yr}$ \\
\hline Estimated energy yield & $5537.4 \mathrm{kWh} / \mathrm{yr}$ \\
\hline Total energy consumption of building & $261,384.0 \mathrm{kWh} / \mathrm{yr}$ \\
\hline Percentage of RE generated & $2.11 \%$ \\
\hline
\end{tabular}

\section{Illuminance}

Multi-purpose hall of Student Pavilion is relying on natural daylight during the day time. The luminance level as shown in Figure 1 from $10 \mathrm{am}$ until $6 \mathrm{pm}$ is above 300 lux. The data showed that the hall would not need to use artificial lightings during the period of time since the illuminance for normal visual tasks such as conference rooms or gymnasium, the lighting intensity should be 300 lux [18].

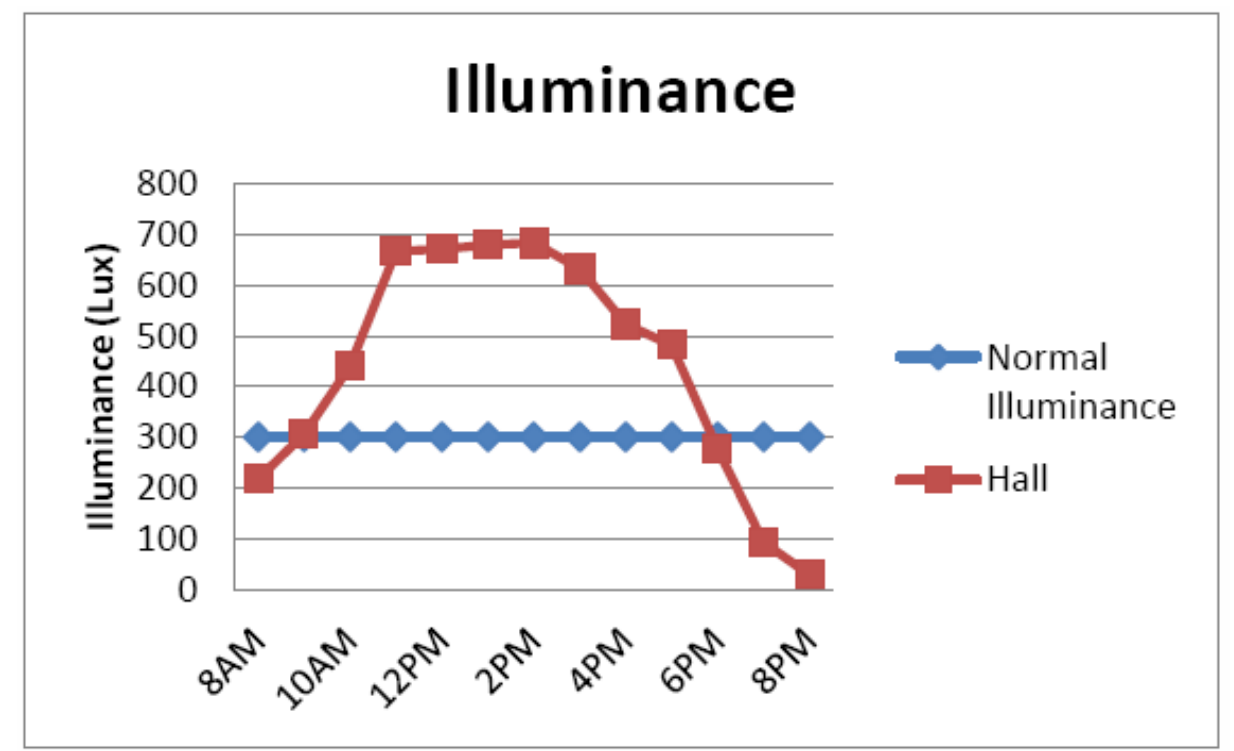

Figure 1: Illuminance of multi-purpose hall and normal illuminance.

\section{Thermal Comfort}

The ambient temperature and humidity of Student Pavilion had been measured in order to compare it with human thermal comfort. According to the guideline given by Malaysia Energy Efficiency Guideline, the temperature for air-conditioned office in most conditions is within the thermal comfort of $23-26^{\circ} \mathrm{C}$ [18]. In order to integrate the sustainability development in the assessment, the range of thermal comfort chosen for this study is $26^{\circ} \mathrm{C}$. The temperature in the multi-purpose hall was measured using a thermocouple attached to a logger. The temperature was above the comfort temperature most of the day time without air-conditioning system and without people inside as shown in Figure 2. Although it was designed for functions with air-conditioning system, but it should however rely on natural ventilation for an acceptable inside temperature. Nevertheless, the hall is designed with fully twisted door to allow the maximum of air movement entering the hall and still the measured temperature in the afternoon when all doors is fully open is $29.6^{\circ} \mathrm{C}$ as shown in Figure 2. 


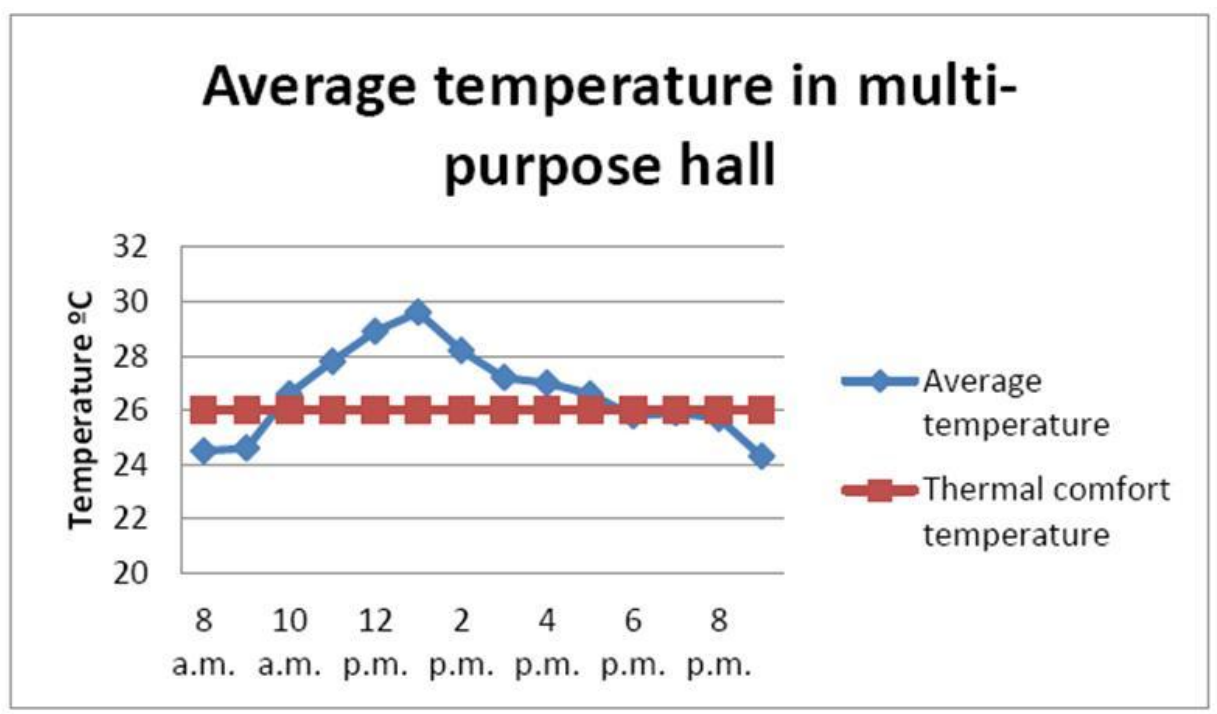

Figure 2: Average temperature in multi-purpose hall

\section{E. Rainwater harvesting}

In Student Pavilion, there is a rainwater harvesting system. The harvesting area is located at the commercial shop area. The rainwater harvesting is collected from the runoff rainwater from roof top. It has a separate water storage tanks and additional pressure boosting equipment and filtering system. There are 10 tanks for the storage of rainwater size $1 \mathrm{~m} \times 1 \mathrm{~m} \times 0.5 \mathrm{~m}$. Each tank is $0.5 \mathrm{~m}^{3}$ in size. These tanks supply water to the toilet flushing use and basins. Since the rainwater is harvested just for toilet flushing and basins, so the volume of the water required had been studied. Since Student Pavilion is a public area, a study of the toilet user had been carried out. Table 2 shows the detail of water consumption. User for the basin is neglected since it is insignificant compared to the toilet flush. In the study, the number of users of toilet has been recorded. There are average of 214 toilet users. Assume that each toilet user flushes the toilet once and each flush is up to 6 liter.

Table 2:Water consumption at Student Pavilion

\begin{tabular}{|l|c|c|}
\hline Water consumption & During Semester & During Semester Break \\
\hline Number of user & 214 & 47 \\
\hline Toilet capacity (liter) & 6 & 6 \\
\hline Daily water consumption (liter) & 1,284 & 282 \\
\hline Monthly water consumption (liter) & 38,520 & 8,460 \\
\hline Yearly water consumption (liter) & 462,240 & 101,520 \\
\hline
\end{tabular}

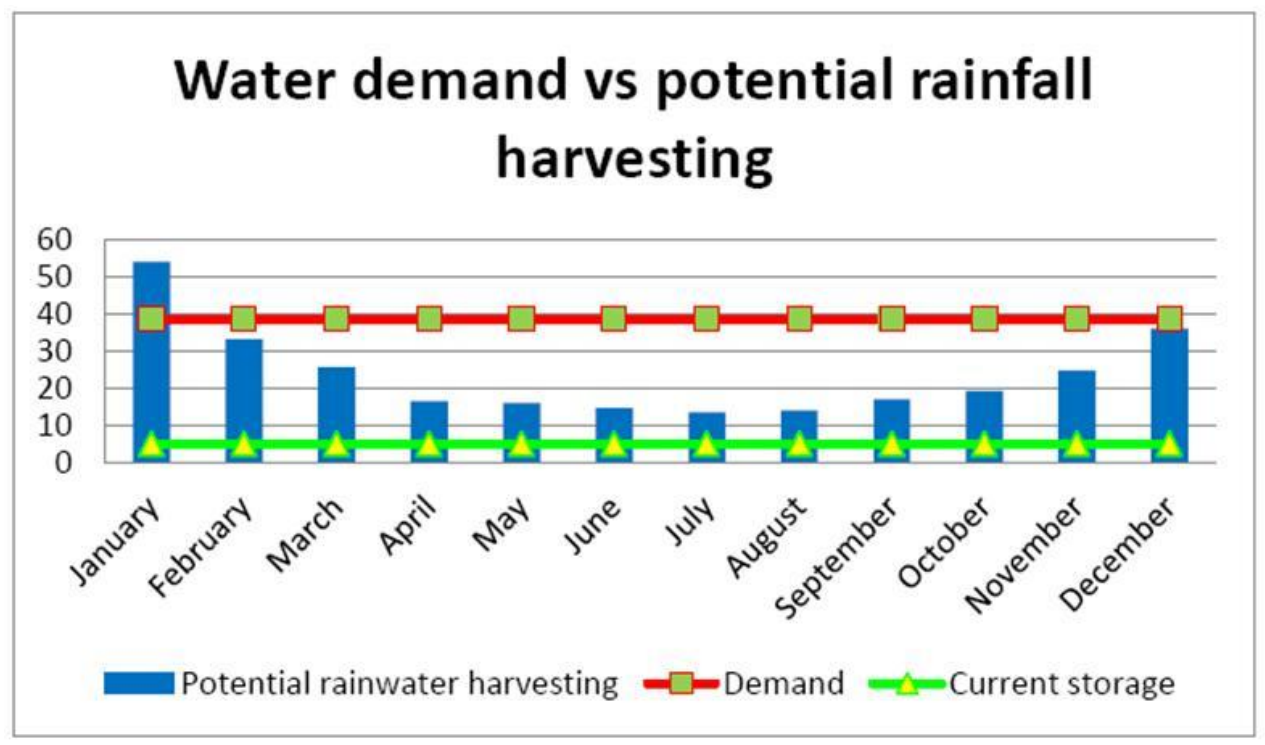

Figure 3: Water demand vs. potential rainfall harvesting

Figure 3 shows that the water demand for Student Pavilion is higher than the current storage tank can provide. When the water is less than a certain level, treated water will be pumped into the storage tank. Since the potential of rainfall harvesting is higher than the current storage, the capacity of storage tank can be increased in order to cater with the demand of water and reduce the dependent of treated water. 


\section{UNIMAS e-Journal of Civil Engineering: Volume 5, Issue 1}

\section{CONCLUSION}

After the study, it is obtained that Student Pavilion needs some improvements in some criteria in order to achieve Platinum standard in Green Building Index (GBI). The building of Student Pavilion has an Overall Thermal Transfer Value of 34.08 which is less than 50 as required by GBI rating guidelines. Lower OTTV means the building gain less external heat through the building envelope and hence the electricity required for air conditioning is reduced. In the aspect of lighting and illuminance, Student Pavilion is greatly relying on natural day light. There are motion sensor and photo sensor located at the deck and corridor of Student Pavilion. When the ambient brightness is low, the light will be switchedon accordingly to provide sufficient brightness. Besides that, in the multi-purpose hall, an illuminance test had been carried out. When the illuminance in the room is less than 300 lux, artificial light is switched on in order to provide sufficient brightness for occupants. Solar panel at Student Pavilion can annually provide 5,537.4 kWhr/year. However, it is insufficient to support the usage of building electricity as the building consumes up to $151,090.06 \mathrm{kWh} / \mathrm{yr}$, with BEI of $90.54 \mathrm{kWh} / \mathrm{m}^{2} / \mathrm{yr}$.

In the section of indoor environment quality, thermal comfort is the most concerned. Temperature at the multi-purpose hall and other area of Student Pavilion had been studied. The temperature measured at Student Pavilion is not within the range of thermal comfort. For water efficiency, the rain harvesting system in Student Pavilion and the rain fall intensity in Kota Samarahan had been studied. At current stage, the storage tank for rainwater harvesting system is insufficient to cater with the demand.

\section{REFERENCES}

[1] Miller, J. (2010). Tackling Global Climate Change- Meeting Local Priorities. World Green Building Council.

[2] KeTTHA. (2009, September). Incentives for Renewable Energy, Energy Efficiency \& Green Building in Malaysia. Putrajaya, Wilayah Persekutuan, Malaysia.

[3] "Ninth Malaysia Plan", The Star, November, 2011.

[4] Abdullah b. Hj Ahmad Badawi. (31 March 2006). Introducing The Motion To Table The Ninth Malaysia Plan, 2006-2010. Speech at TheDewan Rakyat, Kuala Lumpur.

[5] Aun, A. C. (2004). Energy Efficiency: Designing Low Energy Buildings Using Energy 10. PertubuhanArkitek Malaysia.

[6] Aun, A. C. (2009). Green Building Index - MS1525. PertubuhanArkitek Malaysia.

[7] N.d. (1980). Energy conservation in new building design. In ASHRAE Standard. Atlanta: GA: ASHRAE.

[8] Overall Thermal Transfer Value in Building 1995. (2005). Retrieved 11 26, 2011, from Buildings Department (BD) http://www.bd.gov.hk/english/documents/code/e_ottv.htm

[9] Hasanuzzaman, M. (2009). Overall Thermal Transfer Value of Residential Buildings in Malaysia. Journal of Applied Sciences , 2130 - 2136.

[10] Department of Standard Malaysia. (2007). Malaysian Standard MS 1525:2007. Code of Practice on Energy Efficiency and Use of Renewable Energy for Non-Residential Buildings (First Revision). Department of Standards Malaysia.

[11] Oh, T.H., Pang, S.Y. (2010). Energy policy and alternative energy in Malaysia: issues and challenges for sustainable growth. Renewable and Sustainable Energy Reviews, 1241-52.

[12] Saidur, R., Rahim, N.A., Masjuki, H.H., Mekhilef, S., Ping, H.W. and Jamaluddin, M.F. (2009). End-use energy analysis in the Malaysian industrial sector. Energy, 153-8.

[13] Wesolowski, J. (1987). An overview of the indoor air quality problem: The California approach. Clean Air, 134-142.

[14] R. Daghigh, NM Adam, K. Sopian and BB Sahari. (2009). Thermal comfort of an air-conditioned office through different windows-door opening arrangement. Building Services Engineering Research and Technology, 49-63.

[15] Vickers, A. (2002, June). Water Use and Conservation. Amherst, MA WaterplowPress , p. 434.

[16] Water Efficiency Manual. (2009). State of North Carolina: Division of Pollution Prevention and Environmental Assistance and Division of Water, Environmental Assistance and Devision of Water Resources of the N.C.Department of Environment and Natural Resources, and Land-of-Sky Regional Council.

[17] The Illuminance Handbook, Code No. 20750 690, METREL, 2002.

[18] Green Building Index Sdn Bhd. (n.d.). Green Building Index Fact Sheet. Retrieved November 20, 2011, from Green Building Index: http://www.greenbuildingindex.org/Resources/GBI\%20Documents/GBI\%20Fact\%20Sheet\%20V1.0.pdf

[19] Hussein, I. (2009). Fields Study on Thermal Comfort in Malaysia. ISSN 1450-216X Vol. 37 No. 1, pp. $132-152$. 